\title{
N-terminal polypeptide derived from vMIP-II exerts its antitumor activity by inhibiting the CXCR4 pathway in human glioma
}

\author{
QINGLING YANG ${ }^{1,2^{*}}$, HAIHUA WU ${ }^{3 *}$, HAIFENG WANG ${ }^{3}$, YU LI $^{3}$, \\ LINGYU ZHANG ${ }^{3}$, LIHUA ZHU ${ }^{3}$, WENRUI WANG ${ }^{4}$, JIHONG ZHOU $^{2}$, YINGXIAO FU $^{5}$, \\ SULIAN CHEN $^{2}$, QIONG WU ${ }^{6}$, CHANGJIE $\mathrm{CHEN}^{2}$ and CONGZHAO ZHOU ${ }^{1}$ \\ ${ }^{1}$ Hefei National Laboratory for Physical Sciences at Microscale and the Innovation Center for
} Cell Signaling Network, School of Life Sciences, University of Science and Technology of China, Hefei, Anhui 230026; ${ }^{2}$ Department of Biochemistry and Molecular Biology, Bengbu Medical College; ${ }^{3}$ Clinical Testing and Diagnose Experimental Center of Bengbu Medical College; Departments of ${ }^{4}$ Biotechnology and ${ }^{5}$ Bioscience, Bengbu Medical College; ${ }^{6}$ Department of Medical Oncology, First Affiliated Hospital of Bengbu Medical College, Bengbu, Anhui 233030, P.R. China

Received October 15, 2016; Accepted February 28, 2017

DOI: 10.3892/ijo.2017.3906

\begin{abstract}
Emerging evidence demonstrates that the stromal derived factor-1 (SDF-1 $\alpha) / C X C R 4$ axis is associated with tumor aggressiveness and metastasis, including glioma, the most common brain cancer. In the present study, we demonstrated that a novel designed peptide NT21MP of viral macrophage inflammatory protein II, targeting CXCR4 inhibits SDF-1 $\alpha$-induced activation in glioma. The effects of NT21MP on CXCR4 expression, cell survival and migration were assessed on the human glioma cell line U251 and SHG-44 exposed to SDF-1 $\alpha$, by western blotting, MTT assay, flow cytometry and Transwell migration assay. Our results illustrated that NT21MP inhibited SDF-1 $\alpha$ induced proliferation, migration and invasion by upregulated pro-apoptotic genes (Bak1 and caspase-3) and downregulated Bcl-2/Bax as well as cell cycle regulators (cyclin D1 and CDK4) to arrest cell cycle in G0/G1 phase and promote apoptosis. By RT-qPCR and immunofluorescence we found that CXCR4 was highly expressed in SHG-44 cells. Our results from wound healing and Transwell invasion assays indicated silencing of CXCR4 significantly inhibited the SDF- $1 \alpha$-induced migration and
\end{abstract}

Correspondence to: Professor Changjie Chen, Department of Biochemistry and Molecular Biology, Bengbu Medical College, East Sea Road 2600, Bengbu, Anhui 233030, P.R. China

E-mail: tochenchangjie@163.com

Professor Congzhao Zhou, Hefei National Laboratory for Physical Sciences at Microscale and the Innovation Center for Cell Signaling Network, School of Life Sciences, University of Science and Technology of China, Hefei, Anhui 230026, P.R. China

E-mail: zcz@ustc.edu.cn

*Contributed equally

Key words: brain gliomas, viral macrophage inflammatory protein II, N-terminus peptide (NT21MP), CXCR4, SHG-44, U251 invasion; similarly, flow cytometry showed that treatment with si-CXCR4 affected cell cycle and induced cell apoptosis in SHG-44. However, these effects were significantly weakened by NT21MP. In conclusion, the present study indicates that NT21MP plays a regulatory role in the SDF-1 $\alpha / C X C R 4$ axis and further manages the invasion, migration, apoptosis and cell cycle of glioma cells. Thus, NT21MP might represent a novel therapeutic approach against glioma.

\section{Introduction}

Glioma is the most common brain tumor, accounting for $1 / 3-2 / 3$ of adult intracranial tumors. Its pathogenesis is complicated and no radical cure is available. Current treatment is mainly surgery, supplemented by chemotherapy and radiation. However, due to glioma features such as invasive growth and metastasis, this comprehensive treatment cannot achieve good efficacy and also have negatively influences on the quality of life (1). Therefore, it is essential to discover novel therapeutic agents for improving the treatment outcome in patients diagnosed with glioma.

CXCR4 is a well-known G-protein coupled receptor(GPCR) for the small chemokine stromal-derived factor SDF-1 $\alpha$, which is also known as CXCL12. It has been reported that CXCR4 is overexpressed in many tumor cells, including glioma, colorectal, breast, lung, prostate and cervical cancer (2-4). Consistently, high expression of CXCR4 was observed in highly invasive glioma stem cells (5). SDF-1 $\alpha$ promotes tumor growth in a paracrine fashion by directly stimulating tumor cell proliferation and survival via CXCR4. Moreover, interruption of CXCR4 and SDF-1 $\alpha$ axis has demonstrated antitumor growth activities in a variety of preclinical tumor models (6-8). Therefore, it is necessary and of great significance to develop a CXCR4 antagonist targeting CXCR4 for providing more effective strategy for the treatment of glioma.

The CXCR4 antagonist Plerixafor (AMD3100) is the most studied and clinically advanced compound that inhibits SDF-1 $\alpha /$ CXCR4 signaling $(9,10)$. It has been reported that 
Table I. Primers used for real-time PCR.

\begin{tabular}{lll}
\hline Name & \multicolumn{1}{c}{ Forward primer } & \multicolumn{1}{c}{ Reverse primer } \\
\hline Bak1 & CCCAGGACACAGAGGAGGTTT & GCCTCCTGTTCCTGCTGATG \\
CDK4 & GGTGACAAGTGGTGGAACAG & GCCCAATCAGGTCAAAGATT \\
CDK6 & CCCACTGAAACCATAAAGGA & ACCACAGCGTGACGACCA \\
Cyclin D1 & AGGAGAACAAACAGAATCA & TAGGACAGGAAGTTGTTG \\
Bcl-2 & ATGTGTGTGGAGAGCGTCAA & ACAGTTCCACAAAGGCATCC \\
Bax & GGGGACGAACTGGACAGTAA & CAGTTGAAGTTGCCGTCAGA \\
SDF-1 $\alpha$ & CCGCGCTCTGCCTCAGCGACGGGAAG & CTTGTTTAAAGCTTTCTCCAGGTACT \\
GAPDH & CAGCCTCAAGATCATCAGCA & TGTGGTCATGAGTCCTTCCA \\
\hline
\end{tabular}

long-term use of AMD3100 could result in cardiotoxicity and other adverse events (11). Thus, it is important to search for new safer and selective CXCR4 inhibitors suitable for glioma.

Virus macrophage inflammatory protein-II (vMIP-II) is a low molecular weight protein encoded by the HHV-8 K4 gene, which is an analogue of human chemotactic factor (12). The viral macrophage inflammatory protein-II (vMIP-II) shows a broad spectrum interaction with both $\mathrm{CC}$ and $\mathrm{CXC}$ chemokine receptors including CCR5 and CXCR4 (13). Its N-terminal has been reported to be the site with high affinity binding to CXCR4 (14). In our previous study, we developed a synthetic version of the 21-residue N-terminal of vMIP-II (NT21MP), and demonstrated that NT21MP is a potent antagonist of SDF- $1 \alpha$ and CXCR4, in that it inhibited SDF-1 $\alpha$-induced migration, inhibited cellular proliferation, promoted apoptosis by downregulating CXCR4 expression, and inhibited breast cancer progression and metastasis in vitro and in vivo $(15,16)$. In the present study, we explored whether NT21MP inhibits cell growth and invasion, as well as induces apoptosis in U251 and SHG-44 cells. Moreover, we determined whether NT21MP exhibits its antitumor function through regulation of $\mathrm{SDF}-1 \alpha / \mathrm{CXCR} 4$ in glioma cells.

\section{Material and methods}

Reagents and antibodies. Human glioma cell lines SHG-44 and U251 were purchased from Cell Bank of the Chinese Academy of Sciences (Shanghai, China). NT21MP was designed by our laboratory and synthesized by GL Biochem Ltd. (Shanghai, China). The amino acid sequence information of the NT21MP is H-D-leu-D-Gly-D-Ala-D-Ser-D-Trp-DHis-D-Arg-D-Pro-D-Asp-D-Lys-Cys-Cys-Leu-Gly-Tyr-GlnLys-Arg-Pro-Leu-Pro-OH. Human-SDF-1 $\alpha$ was purchased from PeproTech (Rocky Hill, NJ, USA). AMD3100 and 3-(4,5-dimethylthiazol-2-yl)-2,5-diphenyltetrazolium bromide (MTT) were obtained from Sigma-Aldrich (St. Louis, MO, USA). Primary antibodies against Bcl-2, Bax, caspase-3, cyclin D1 and $\beta$-actin were obtained from Santa Cruz Biotechnology (Santa Cruz, CA, USA). A mouse anti-human CXCR4 mAb was purchased from Abcam (clone: 44716.111). Secondary antibodies conjugated to horseradish peroxidase (HRP) were purchased from ZSGB-Bio, Co., Ltd. (Beijing, China). Apoptosis kit was obtained from BD Biosciences (San Jose, CA, USA). Hoechst 33258 was purchased from
Sigma-Aldrich. Reverse transcription kit was obtained from Thermo Fisher Scientific (Waltham, MA, USA) and the SYBR Premix Dimer Eraser ${ }^{\mathrm{TM}}$ reagent kit from Takara, Co., Ltd. (Shiga, Japan).

Cell culture and treatment. The human glioma cell lines SHG-44 and U251 were cultured in Dulbecco's modified Eagle's medium (DMEM)/high glucose medium containing $10 \%$ fetal bovine serum (FBS) at $37^{\circ} \mathrm{C}$, in a humid atmosphere with $5 \% \mathrm{CO}_{2}$ and passaged every 3 days. Cells were stimulated or not with $0.1 \mu \mathrm{g} / \mathrm{ml} \mathrm{SDF}-1 \alpha$ and cultured in absence or in presence of $1 \mu \mathrm{g} / \mathrm{ml} \mathrm{NT21MP}$ or AMD3100. Cells in logarithmic phase were used in all experiments.

Quantitative RT-PCR. Total RNA extraction and cDNA synthesis were conducted with the above kits according to the manufacturer's instructions. All real-time PCR experiments were performed by using an ABI 7500 real-time PCR system (Applied Biosystems, Inc., Foster City, CA, USA) and the SYBR Premix Dimer Eraser ${ }^{\mathrm{TM}}$ reagent kit (Takara Bio). All reactions were performed in triplicate. GAPDH was used as internal reference to normalize the variability in expression levels and the fold-change of target gene in cells relative to their respective control was reported as $2^{-\Delta \Delta \mathrm{Ct}}$. Primers used for real-time PCR are shown in Table I.

Immunofluorescence analysis. Cells were plated into the 6 -well plate at the density of $2 \times 10^{5}$ cells $/ \mathrm{ml}$, treated with SDF-1 $\alpha$, NT21MP or with AMD3100 as described in 'Cell culture and treatment' and incubated at $37^{\circ} \mathrm{C}$ with $5 \% \mathrm{CO}_{2}$ overnight; after washing with pre-cooled PBS twice, cells were fixed for $20 \mathrm{~min}$ with fixative, treated with $0.2 \%$ Triton $\mathrm{X}-100$ for $5 \mathrm{~min}$ at room temperature, washed with phosphatebuffered saline (PBS) 3 times and blocked with 4\% BSA for $30 \mathrm{~min}$. Then, anti-CXCR4 primary antibody (1:200) and goat anti-mouse secondary antibody labeled with FITC (1:200) were sequentially added. Counterstaining was carried out with Hoechst 33258 at room temperature. After washing, cells were stained in $10 \mathrm{mg} / \mathrm{ml}$ Hoechst solution. Image acquisition and processing were conducted by using Leica Confocal Software (Leica Microsystems). All reactions were performed in triplicate.

Cell proliferation analysis. Cells were seeded in 96-well plates at the density of $5 \times 10^{4}$ cells in $100 \mu \mathrm{l} /$ well in triplicate 
Table II. CXCR4 siRNA fragments.

\begin{tabular}{llc} 
Name & \multicolumn{1}{c}{ Sense } & Antisense \\
\hline CXCR4-homo-1 & GAAGCAUGACGGACAAGUA & UACUUGUCCGUCAUGCUUC \\
CXCR4-homo-2 & GGAAGCUGUUGGCUGAAAA & UUUUCAGCCAACAGCUUCC \\
CXCR4-homo-3 & CUGUCCUGCUAUUGCAUUA & UAAUGCAAUAGCAGGACAG
\end{tabular}

and were treated with SDF-1 $\alpha$, NT21MP or with AMD3100 as described in 'Cell culture and treatment' for 24, 48 and $72 \mathrm{~h}$ at $37^{\circ} \mathrm{C}$ and $5 \% \mathrm{CO}_{2}$. Afterwards, $20 \mu 1$ MTT solution $(5 \mathrm{mg} / \mathrm{ml})$ was added in each well and further incubated for $4 \mathrm{~h}$. After removing the cell culture medium, dimethyl sulfoxide (DMSO) $(150 \mu \mathrm{l})$ was added in each well and OD values were obtained on a microplate reader at $490 \mathrm{~nm}$ to assess growth inhibition rate of human glioma as follows: Growth inhibition rate $(\%)=1-($ average OD in experiment group/average OD in control group) x 100\%. Each experimental group was performed in five replicates for each time-point and all the experiments were repeated three times independently.

Wound healing analysis. Cells were seeded in 96-well plates at the density of $1 \times 10^{5}$ cells $/ \mathrm{ml}$, treated with SDF-1 $\alpha$, NT21MP or with AMD3100 as described in 'Cell culture and treatment' and incubated at $37^{\circ} \mathrm{C}$ overnight. At $80-90 \%$ confluency, a wound was generated by scraping with a $10-\mu 1$ sterile pipette tip. Then cells were washed twice with PBS and were further cultured at $37^{\circ} \mathrm{C}$ with $5 \% \mathrm{CO}_{2}$. After $20 \mathrm{~h}$, the cells in the wounded monolayer were photographed and cell migration was assessed by measuring gap sizes at multiple fields. At least three independent experiments were performed in each cell line.

Transwell analysis. Cell migration assay was performed with Transwell chambers (Corning Costar Corp., Cambridge, MA, USA). Cells were seeded in serum-free medium $\left(3 \times 10^{5}\right.$ cells/well) in the Transwell chambers either with or without NT21MP or AMD3100. Then, the chamber were placed into wells of the 24-well plate which was added with the medium containing 10\% FBS with or without SDF-1 $\alpha$. Cells were cultured at $37^{\circ} \mathrm{C}$ with $5 \% \mathrm{CO}_{2}$ for $18-24 \mathrm{~h}$ and those did not pass through the membrane were removed. Paraformaldehyde (4\%) was used to fix the remaining ones for 20 min followed by Giemsa staining. The migrated cells on the lower side of the filters were defined as invasive cells and counted at x200 magnification in 10 different fields of each filter. All reactions were performed in triplicate.

Cell cycle analysis. Cells were plated into a 6-well plate at the density of $1 \times 10^{5}$ cells $/ \mathrm{ml}$, treated with SDF- $1 \alpha$, NT21MP or with AMD3100 as described in 'Cell culture and treatment' and incubated at $37^{\circ} \mathrm{C}$ with $5 \% \mathrm{CO}_{2}$ for $48 \mathrm{~h}$; then, cells were fixed with $70 \%$ alcohol at $4{ }^{\circ} \mathrm{C}$ overnight. Afterwards, cells were washed with PBS. In order to remove RNA, RNase A $(100 \mu \mathrm{g} / \mathrm{ml})$ was used to digest the fixed cells for $30 \mathrm{~min}$. The staining was carried out with $50 \mathrm{mg} / \mathrm{ml}$ propidium iodide (PI) in PBS Triton X-100 in the dark for another $30 \mathrm{~min}$ at room temperature. Finally, results were acquired by the Muse ${ }^{\mathrm{TM}}$ cell analyzer. At least three independent experiments were performed in each cell line.

Apoptosis analysis. Cells were plated into the 6-well plate at the density of $5 \times 10^{5}$ cells $/ \mathrm{ml}$, treated with SDF-1 $\alpha$, NT21MP or with AMD3100 as described in 'Cell culture and treatment' and incubated at $37^{\circ} \mathrm{C}$ with $5 \% \mathrm{CO}_{2}$. After $24 \mathrm{~h}$, cells were collected and washed twice with PBS. Then, cell density was adjusted to $5 \times 10^{5}$ cells $/ \mathrm{ml}$ with DMEM/high glucose medium containing $1 \%$ FBS; $100 \mu 1$ cell suspension were mixed with $100 \mu \mathrm{l}$ apoptosis reagent and incubated for $30 \mathrm{~min}$ in the dark at room temperature. Finally, results were acquired by the Muse $^{\mathrm{TM}}$ cell analyzer. At least three independent experiments were performed in each cell line.

Transfection. Transient transfections were performed using Lipofectamine or Lipofectamine 2000 reagents (Thermo Fisher Scientific) according to the manufacturer's instructions. CXCR4 siRNA and the negative control siRNA products were purchased from Suzhou GenePharma, Co., Ltd. (Suzhou, China). Transfection were performed as previously reported. CXCR4 siRNA fragments are summarized in Table II.

Western blot analysis. Cells were seeded at the density of $2.5 \times 10^{5}$ cells $/ \mathrm{ml}$, treated with SDF- $1 \alpha$, NT21MP or with AMD3100 as described above and lysed in RIPA buffer $(150 \mathrm{mM} \mathrm{NaCl}, 50 \mathrm{mM}$ Tris-HCl, $\mathrm{pH} 7.5,1 \%$ Nonidet P-40, $0.5 \%$ sodium deoxycholate and $0.1 \%$ SDS), supplemented with protease and phosphatase inhibitor cocktails (Hoffman-La Roche Ltd., Basel, Switzerland). Protein concentrations were determined by BCA protein assay kit (Beyotime Institute of Biotechnology, Haimen, China) and proteins (20 $\mu \mathrm{g} / \mathrm{lane})$ were isolated by SDS-PAGE (10\% polyacrylamide) electrophoresis and then transferred to NC membranes. Then, the membranes were blocked for $2 \mathrm{~h}$ and incubated with primary antibodies overnight at $4^{\circ} \mathrm{C}$. After washing with TBST buffer, the membrane was incubated with secondary antibodies at $37^{\circ} \mathrm{C}$ for $2 \mathrm{~h}$. The membrane was washed with TBST buffer and detected the protein expression levels with a Bio-Rad Gel Imaging System. The anti- $\beta$-actin antibody was used as loading control.

Statistical analysis. Each experiment consisted of three replications. Statistical comparisons between different groups were evaluated using GraphPad Prism 4.0 (Graphpad Software, Inc., La Jolla, CA, USA). Statistical analyses were performed with mean \pm standard deviation $(\mathrm{SD})$ values. $\mathrm{P}<0.05$ was considered statistically significant. 
A
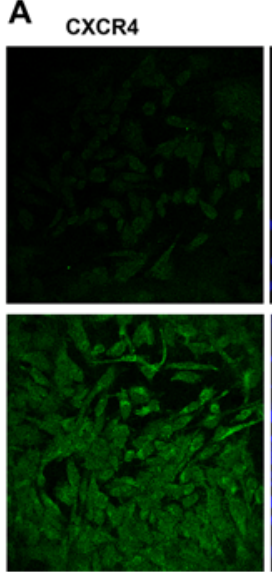

Hoechst
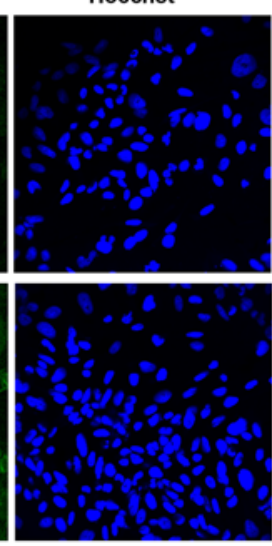

U251
Double labled

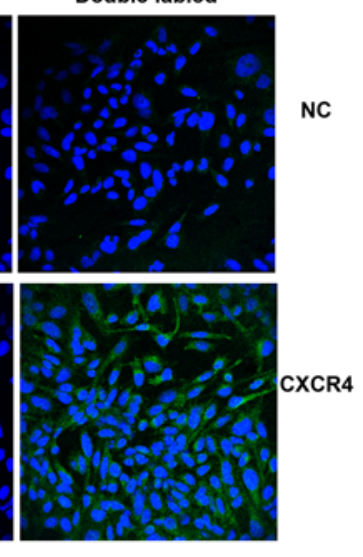

B
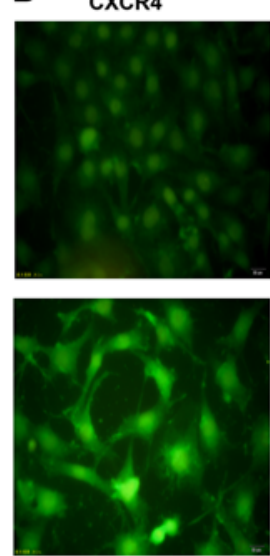

Hoechst
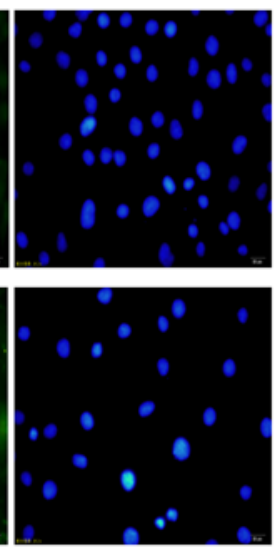

SHG-44
Double labled
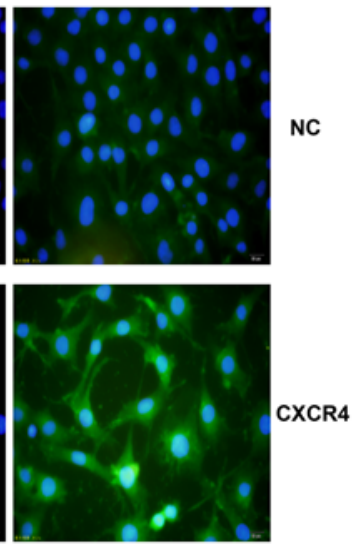

Figure 1. Immunofluorescence staining of CXCR4 protein in vitro. (A) The expression of CXCR4 in U251 cells. (B) The expression of CXCR4 in SHG-44 cells. Both images are at a magnification of $\mathrm{x} 200$.
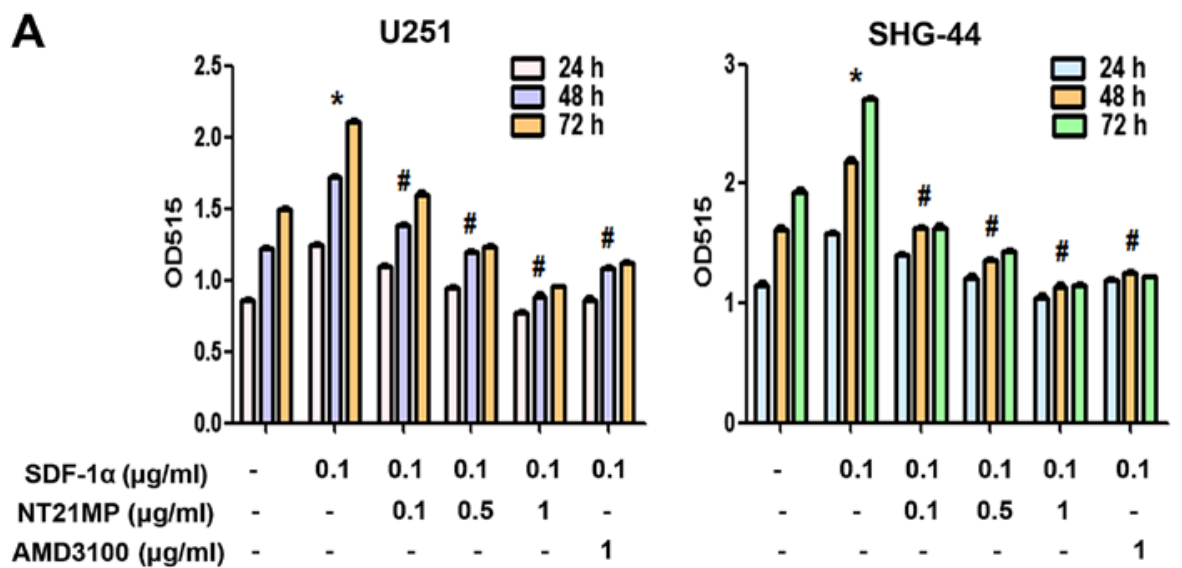

B
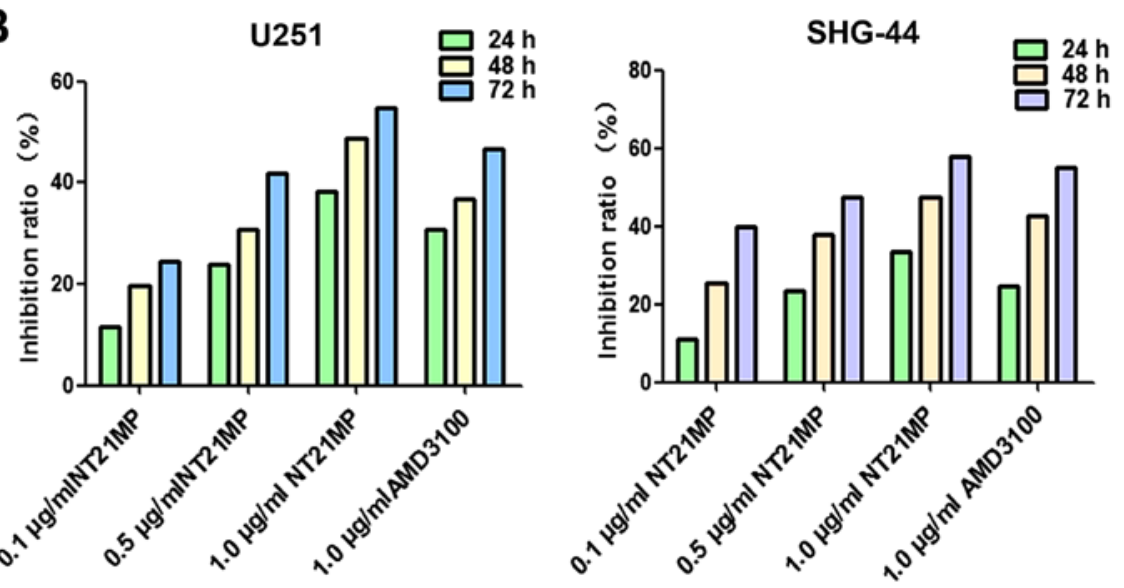

Figure 2. Effects of NT21MP on cell proliferation in U251 and SHG-44 cells. (A) The proliferation of U251 and SHG-44 cells stimulated (+SDF-1 $\alpha$ ) or not (-SDF-1 $\alpha$ ) with $100 \mathrm{ng} / \mathrm{ml}$ of SDF- $1 \alpha$ and treated with NT21MP $(0.1,0.5$ and $1 \mu \mathrm{g} / \mathrm{ml})$ or AMD3100 (1 $\mu \mathrm{g} / \mathrm{ml})$ for 24,48 and $72 \mathrm{~h}$ was performed by MTT assay. Data represent the mean $\pm \mathrm{SD}$ of three independent experiments. ${ }^{*} \mathrm{P}<0.05$ vs. control, ${ }^{\#} \mathrm{P}<0.05$ vs. $+\mathrm{SDF}-1 \alpha$ group. (B) The bar plots show the inhibitory effects of NT21MP $(0.1,0.5$ and $1 \mu \mathrm{g} / \mathrm{ml})$ on cell proliferation for 24,48 and $72 \mathrm{~h}$.

\section{Results}

CXCR4 is expressed at different levels in human glioma U251 and SHG-44 cells. CXCR4 expression in glioma cells was detected by immunofluorescence. As shown in Fig. 1, the results indicated that both U251 and SHG-44 expressed the
CXCR4 protein. Compared with U251 cells, the SHG-44 cell line showed higher expression levels.

NT21MP inhibits SDF-1 $\alpha$-induced human glioma cell proliferation. In order to investigate the possible functional effects of NT21MP on SDF-1 $\alpha$-induced glioma cells, we 


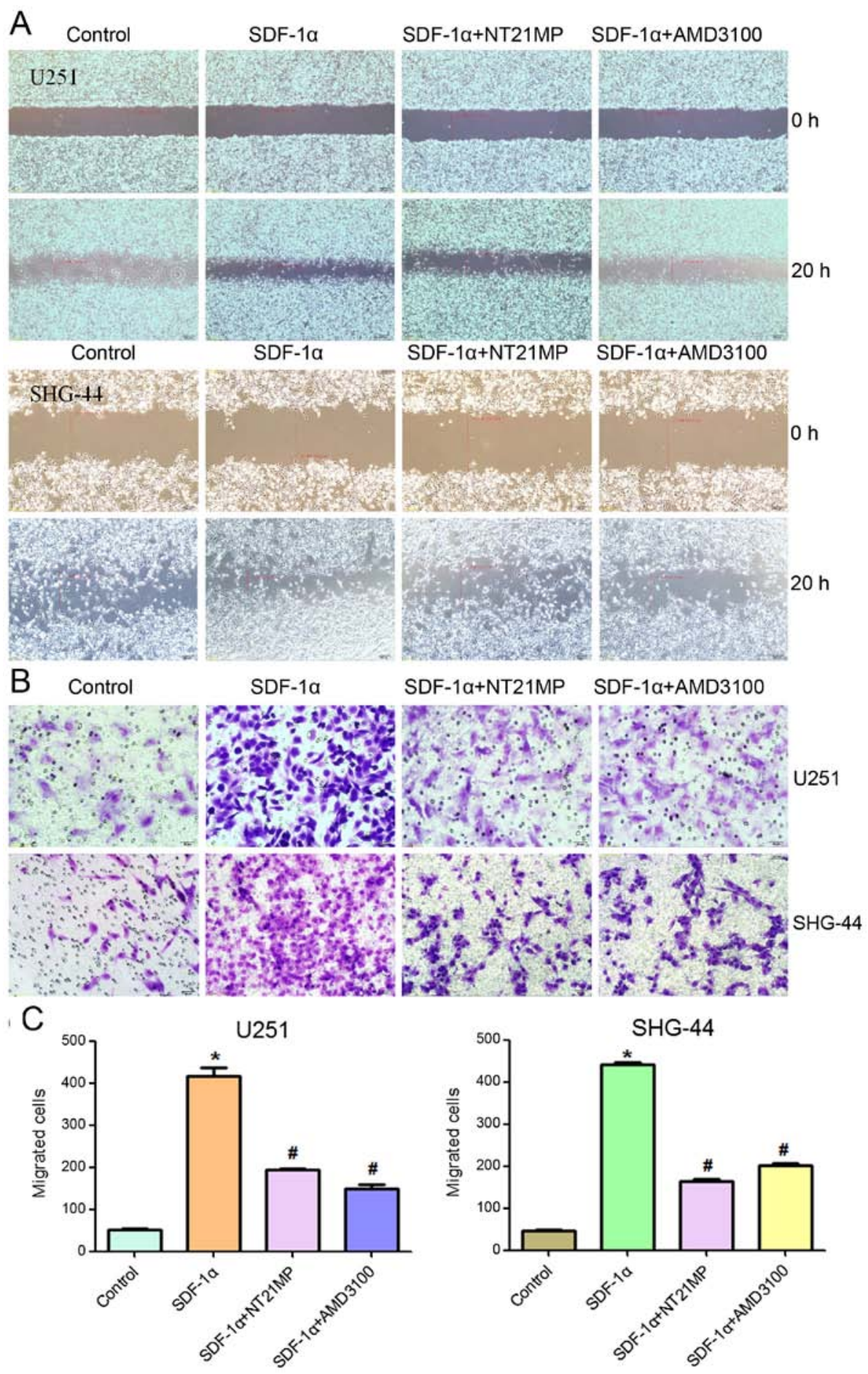

Figure 3. Effects of NT21MP on cell migration and invasion in U251 and SHG-44 cells. The cells were stimulated by (+SDF-1 $\alpha)$ or not (-SDF-1 $\alpha)$ with $100 \mathrm{ng} / \mathrm{ml}$ of SDF-1 $\alpha$ and treated with NT21MP $(0.1,0.5$ and $1 \mu \mathrm{g} / \mathrm{ml})$ or AMD3100 $(1 \mu \mathrm{g} / \mathrm{ml})$. (A) Invasion ability of U251 and SHG-44 cells measured by wound healing assays. (B) Representative images (C) and cartogram of indicated invading cells analyzed by Transwell assay. Scale bar, $50 \mu \mathrm{m}$. Data are mean \pm SD of 5 fields. ${ }^{*} \mathrm{P}<0.05$ vs. control, ${ }^{\#} \mathrm{P}<0.05$ vs. $+\mathrm{SDF}-1 \alpha$ group.

assessed cell proliferation ability after exposure of U251 and SHG-44 cells to various doses of NT21MP using the MTT assay at 24, 48 and $72 \mathrm{~h}$. As shown in Fig. 2A, treatment with SDF-1 $\alpha$ significantly increased cell viability, NT21MP inhibited cell growth in a dose- and time-dependent manner in U251 and SHG-44 cells (Fig. 2B). AMD3100, as a specific inhibitor of CXCR4, inhibited the SDF-1 $\alpha$ induced proliferation $(\mathrm{P}<0.05$; Fig. $2 \mathrm{~A})$ in a time-dependent manner ( $\mathrm{P}<0.05$; Fig. 2B).
NT21MP inhibits SDF-1 $\alpha$-induced migration and invasion in human glioma cell. One of the important functions of $\mathrm{SDF}-1 \alpha / \mathrm{CXCR} 4$ interaction is to regulate cell migration. Therefore, the effects of NT21MP on cell migration were evaluated using a wound healing and Transwell invasion assay, and the results were compared to those cells treated with AMD3100. As shown in Fig. 3, as expected, SDF-1 $\alpha$ promoted cell migration and invasion in $\mathrm{U} 251$ and SHG-44 cells. AMD3100 did not induce significant changes, while NT21MP 
A Control

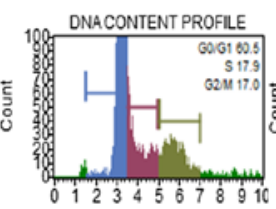

U251 DNACONTENT INDEX

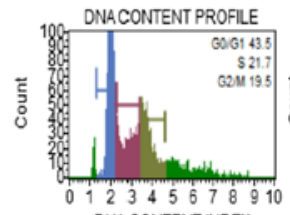

SHG-44

B

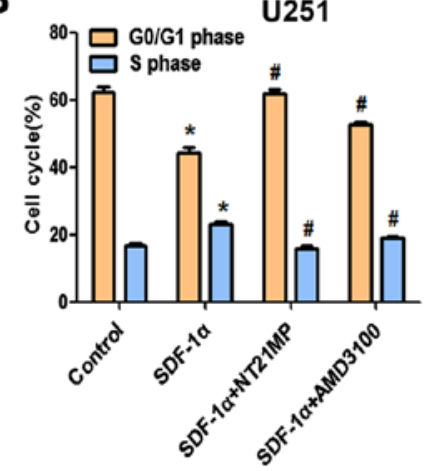

SDF-1 $\alpha+N T 21 M P$ SDF-1 $\alpha+A M D 3100$
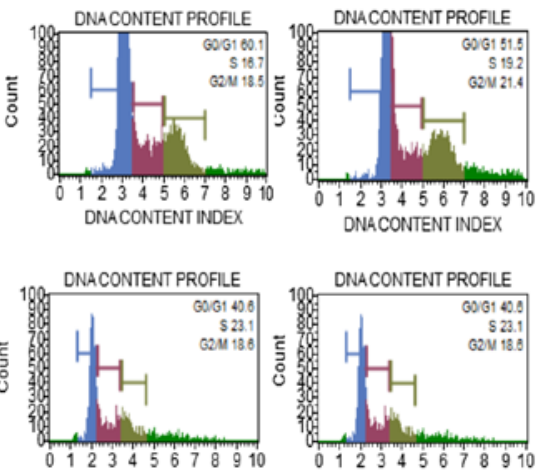

DNACONTENT INDEX

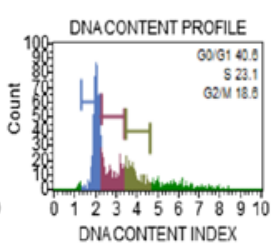

SHG-44

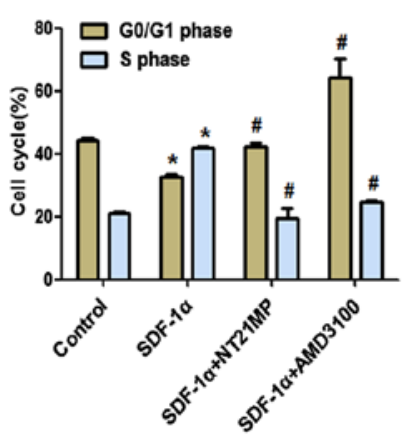

C Control

SDF-1 $\alpha$

SDF-1 $\alpha+N T 21 M P$ SDF-1 $\alpha+A M D 3100$
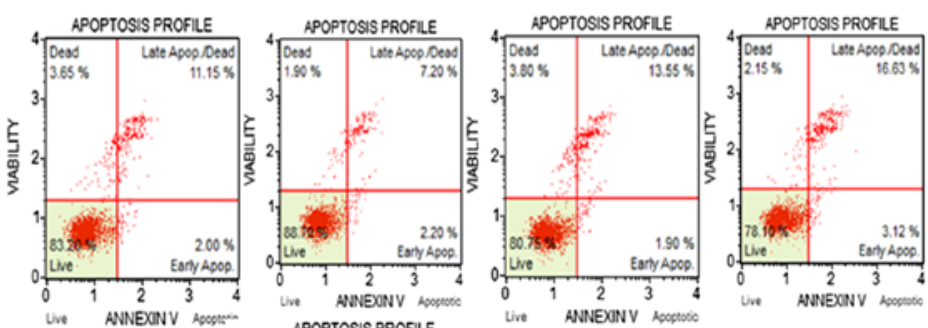

U251
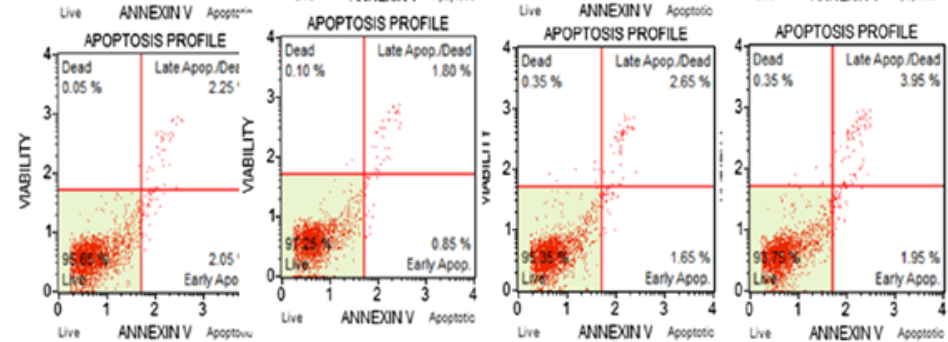

SHG-44
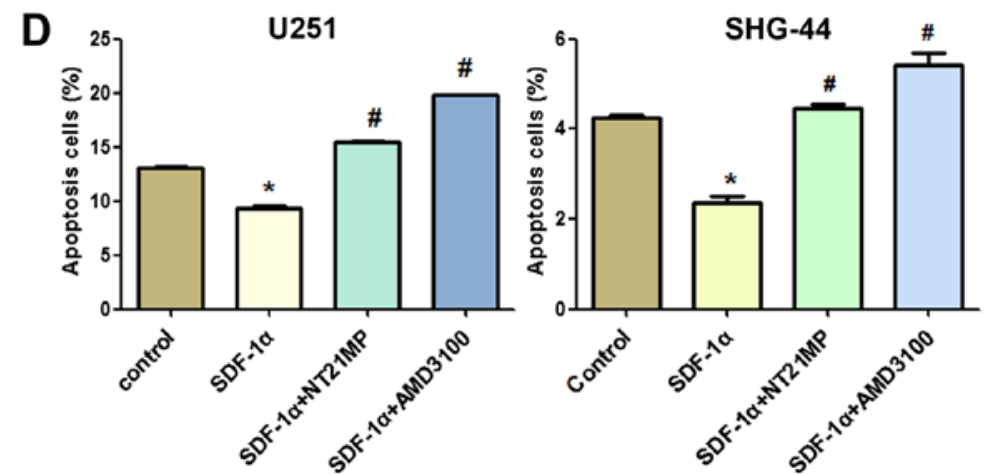

Figure 4. Effects of NT21MP on cell cycle and apoptosis in U251 and SHG-44 cells. The cells were stimulated by (+SDF-1 $\alpha)$ or not (-SDF-1 $\alpha$ ) with $100 \mathrm{ng} / \mathrm{ml}$ of SDF- $1 \alpha$ and treated with NT21MP $(0.1,0.5$ and $1 \mu \mathrm{g} / \mathrm{ml})$ or AMD3100 $(1 \mu \mathrm{g} / \mathrm{ml})$. (A) Cell cycle of the U251 and SHG-44 cells were analyzed by propidium iodide staining and flow cytometry. (B) Bar plots illustrating the percentage of G0/G1 and S phase in U251 and SHG-44 cells. (C) Apoptosis of U251 and SHG-44 cells were evaluated by Annexin V/PI staining and flow cytometry. (D) Bar plots illustrating the percentage of apoptotic cells in U251 and SHG-44 cells. Data are presented as mean \pm SD of three independent experiments. ${ }^{*} \mathrm{P}<0.05$ vs. control, ${ }^{*} \mathrm{P}<0.05 \mathrm{vs}$. +SDF-1 $\alpha$ group. 

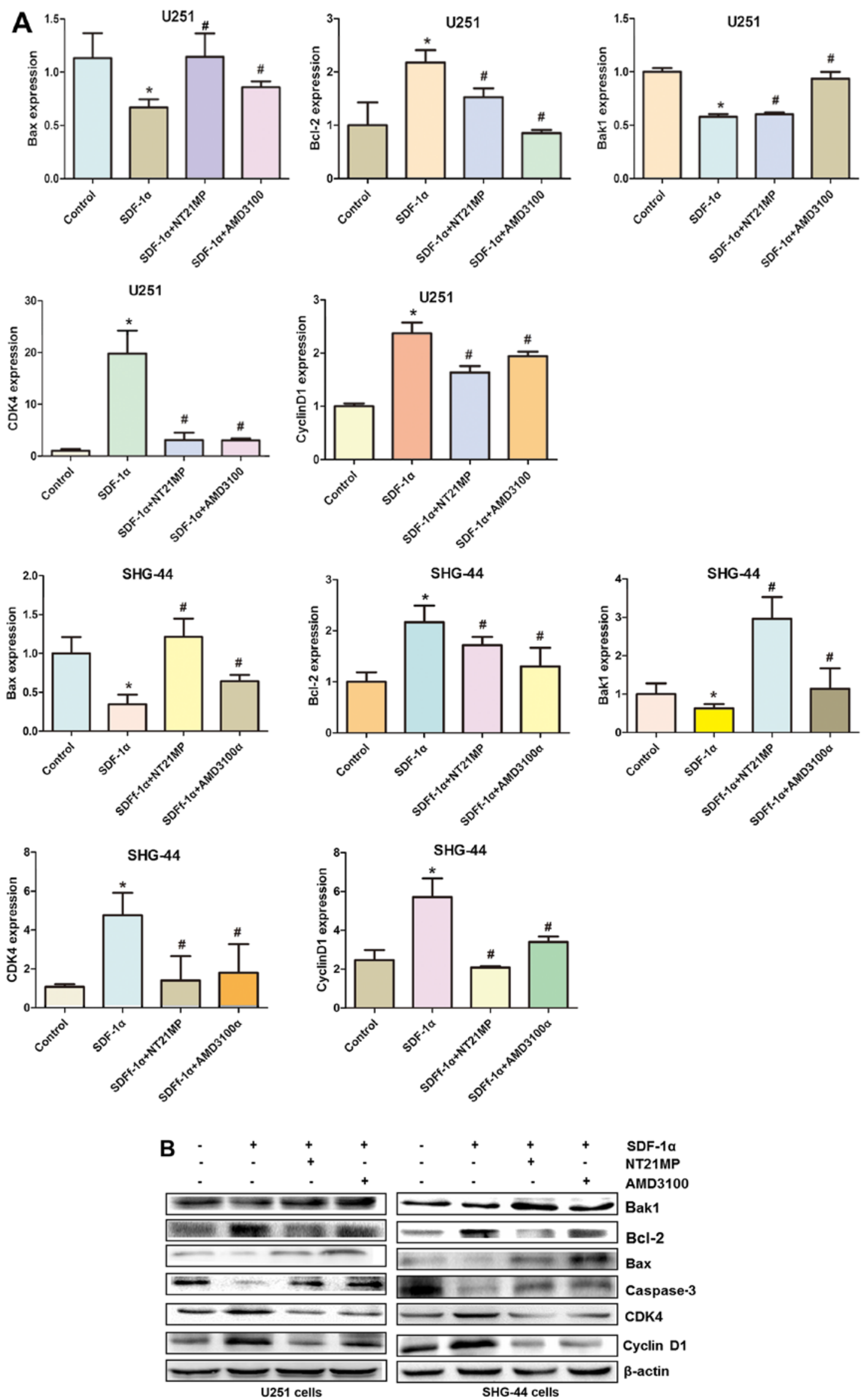

Figure 5. Expression of cell cycle and apoptosis related factors in U251 and SHG-44 cells. The cells were treated with (+SDF-1 $\alpha)$ or not (-SDF-1 $\alpha)$ with $100 \mathrm{ng} / \mathrm{ml}$ of SDF- $1 \alpha$ and NT21MP $(1 \mu \mathrm{g} / \mathrm{ml})$ or AMD3100 $(1 \mu \mathrm{g} / \mathrm{ml})$. (A and B) Quantitative RT-PCR and western blot assay represent the mRNA and protein level of Bak1, Bcl-2, Bax, caspase-3, CDK4 and cyclin D1 in the U251 and SHG-44 cells. The data are the result of three independent experiments and are presented as mean $\pm \mathrm{SD},{ }^{, \mathrm{P}}<0.05$ vs. control, ${ }^{\#} \mathrm{P}<0.05$ vs. $+\mathrm{SDF}-1 \alpha$ group. 

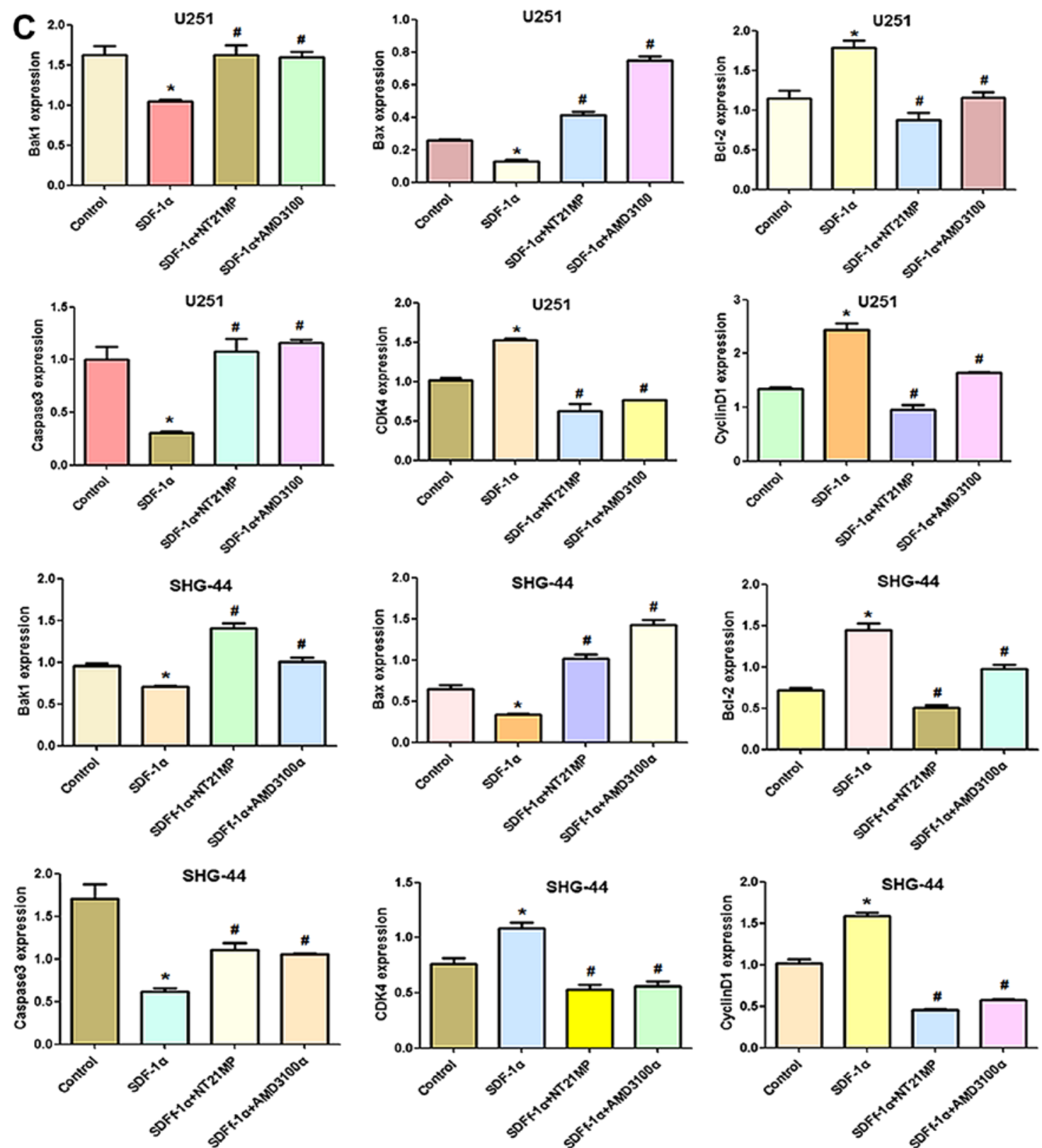

Figure 5. Continued. (C) The bar plots show the quantitative results for cell cycle and apoptosis related protein

significantly reduced the percentage of area occupied by migrating cells, further confirming that NT21MP acted as an antagonist.

NT21MP arrests glioma cells in G0/G1 phase and promotes apoptosis. The role of cell cycle arrest has been implicated in tumor cells proliferation, we performed cell cycle analysis using flow cytometry to determine whether the inhibition of NT21MP on U251 and SHG-44 cell proliferation involved cell cycle changes.

As shown in Fig. 4A and B, when glioma cells were treated with SDF-1 $\alpha$, the percentage of cells in the G0/G1 phase decreased (from 60.5 to $45.6 \%$ for U251 and from 43.5 to $36.9 \%$ for SHG-44) and the percentage of cells in the S phase increased (from 17.1 to $22.3 \%$ for U251, from 21 to $38.9 \%$ for SHG-44, respectively). These results indicated that SDF-1 $\alpha$ induced the cell transition from G0/G1 to S phase. Compared with the SDF-1 $\alpha$ treatment group, the rate of cell growth in the $S$ phase is significantly reduced in glioma cells when treated with NT21MP (for U251 cells, the percentage was from 22.3 to $16.7 \%$, and for SHG-44 cells, from 38.9 to $23.1 \%$ ), while the number of cells in G0/G1 phase was increased, indicating that NT21MP could block the cell cycle of glioma cells at the G0/ G1 phase.

The results of Annexin V/PI double-staining demonstrated that the number of apoptotic cells was significantly decreased by SDF- $1 \alpha$ treatment compared with the untreated cells. As shown in Fig. 4C and D, compared with the SDF-1 $\alpha$ treatment group, NT21MP significantly attenuated the anti-apoptotic effects of SDF-1 $\alpha$-induced in both cell lines, indicating that NT21MP could induce apoptosis in glioma cells. In addition, CXCR4-specific antagonist, AMD3100, prevented SDF-1 $\alpha$-induced anti-apoptosis in glioma cells. 

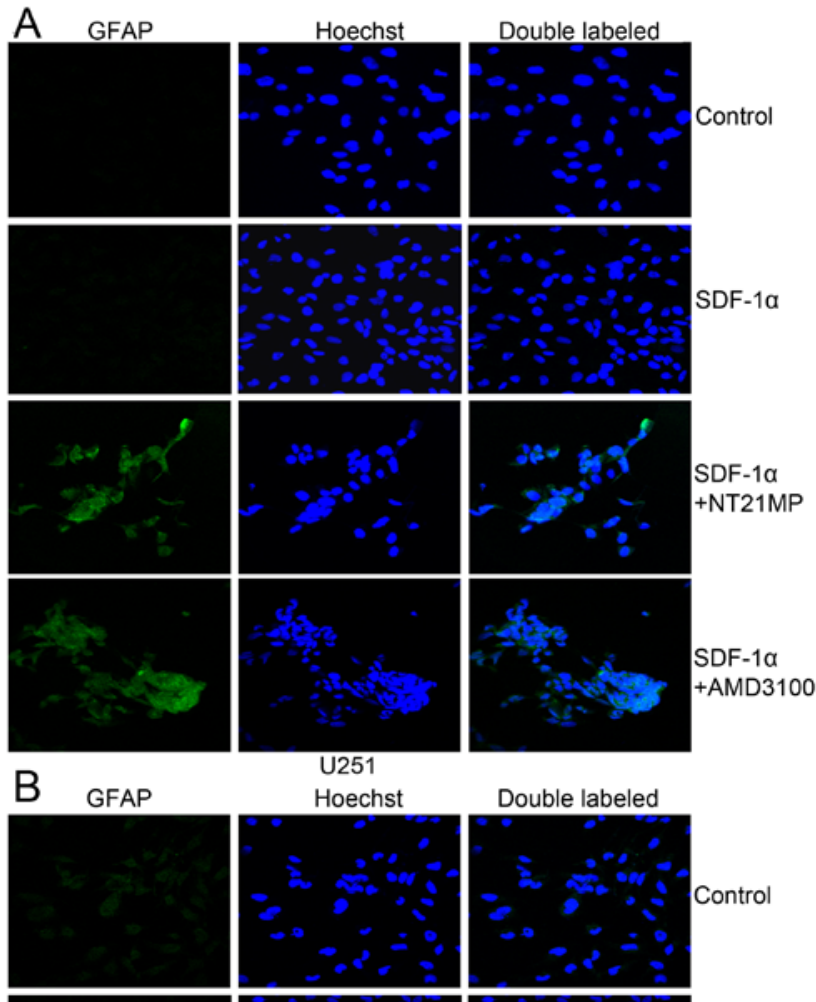

Double labeled
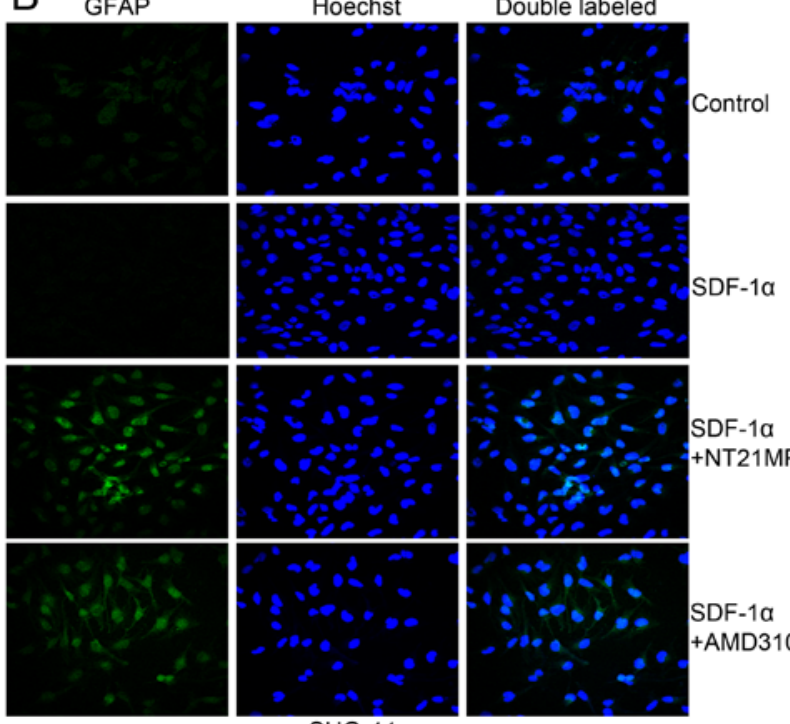

SHG-44
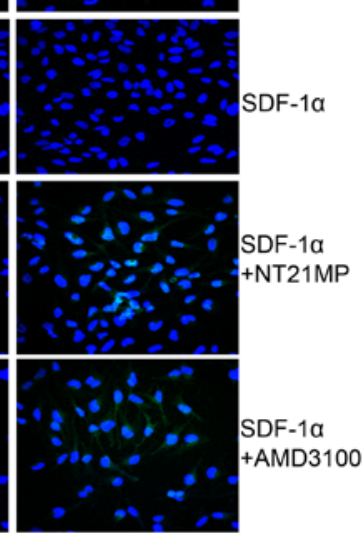

Figure 6. Immunofluorescent staining of GFAP protein in U251 and SHG-44 cells. The cells were treated with $(+\mathrm{SDF}-1 \alpha)$ or not $(-\mathrm{SDF}-1 \alpha)$ with $100 \mathrm{ng} / \mathrm{ml}$ of SDF- $1 \alpha$ and NT21MP $(1 \mu \mathrm{g} / \mathrm{ml})$ or AMD3100 $(1 \mu \mathrm{g} / \mathrm{ml})$. (A) The expression of GFAP in U251 cells. (B) The expression of GFAP in SHG-44 cells. Both images are at a magnification of $\mathrm{x} 200$.

Effects of NT21MP on the expression of cell cycle and apoptosis-related genes. To further explore the molecular mechanisms by which NT21MP arrest glioma cell in G0/G1 phase, qRT-PCR and western blotting assay were applied to analyze the changes of mRNA and protein levels of cell cycle related factors.

Cyclin D1 expression could be used as a biomarker in cell cycle progression. Besides, CDK4 is also recommended as a master regulatory protein in the cell cycle. As shown in Fig. 5, the mRNA and protein levels of cyclin D1 and CDK4 in the SDF-1 $\alpha$ group in the two cell lines were clearly upregulated compared with the control group. A reduction in CDK4 and cyclin D1 mRNA and protein levels was observed in NT21MP treatment group. Quantification of western blots confirmed that the CDK4 and cyclin D1 protein level decrease in NT21MP treatment group.
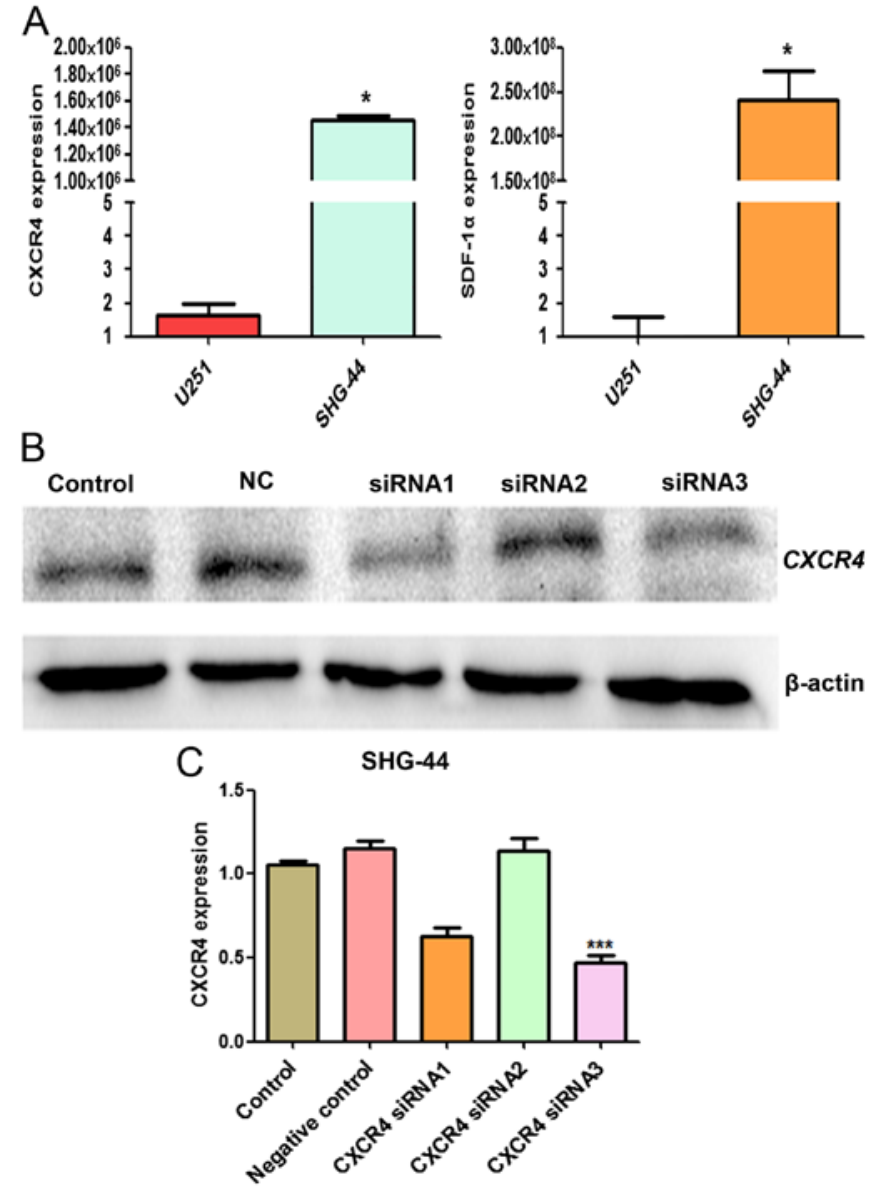

Figure 7. The mRNA and protein level of CXCR4 and SDF-1 $\alpha$ in the U251 and SHG-44 cells. (A) Quantitative RT-PCR showing the mRNA level of CXCR4 and SDF-1 $\alpha$ in the U251 and SHG-44 cells. (B) Western blotting for CXCR4 expression in the SHG-44 cells after nucleofection of CXCR4specific siRNA or a non-targeting control siRNA for $48 \mathrm{~h}$. (C) Quantitative RT-PCR showing CXCR4 expression in the SHG-44 cells after nucleofection of CXCR4-specific siRNA or a non-targeting control siRNA for $24 \mathrm{~h}$. The data are the result of three independent experiments and are presented as mean $\pm \mathrm{SD},{ }^{*} \mathrm{P}<0.05,{ }^{* * *} \mathrm{P}<0.001$.

To evaluate potential mechanisms of SDF- $1 \alpha$-induced activation of the intrinsic pathway, we assessed the effect of SDF- $1 \alpha$ on the mRNA levels of Bcl- 2 as well as Bak1, Bax in U251 and SHG-44 cells. As shown in Fig. 5A, Bcl-2 mRNA levels in U251 and SHG-44 cells were substantially altered under SDF-1 $\alpha$ treatment $(\mathrm{P}<0.05)$, but the Bax and Bak1 levels in glioma cells were decreased by SDF-1 $\alpha$ treatment. Consistent with these results, western blotting showed that SDF-1 $\alpha$ also upregulate Bcl-2 and downregulate Bax and Bak1 at the protein level in the two cell lines (Fig. 5B). The expression level of Bcl-2 was significantly downregulated by NT21MP whereas the expression levels of Bax and Bak1 were upregulated. Together these results suggested that NT21MP significantly attenuated the anti-apoptotic effects of SDF-1 $\alpha$, indicating that NT21MP could induce apoptosis in glioma cells.

NT21MP induces the expression of differentiation-related markers (GFAP) in glioma cells. Previous studies suggested that plasma glial fibrillary acidic protein (GFAP) levels are sensitive and specific for glioma. Therefore, we performed 

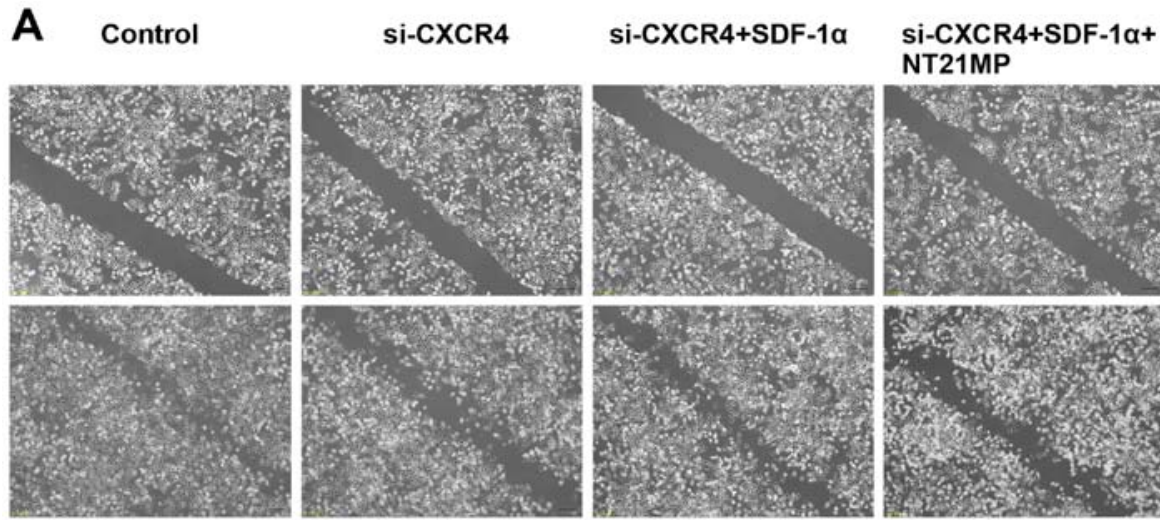

NT21MP

B Control

si-CXCR4
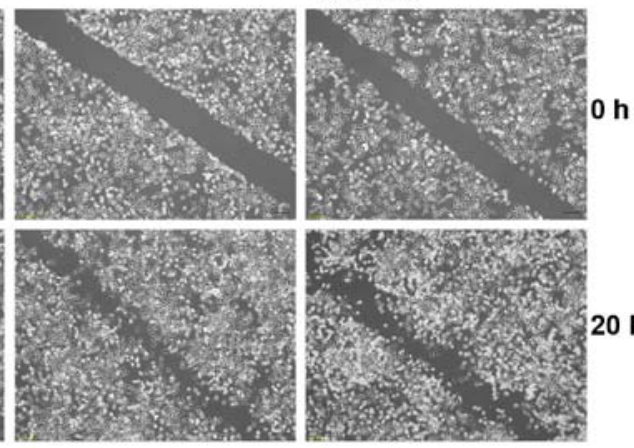

$0 \mathrm{~h}$

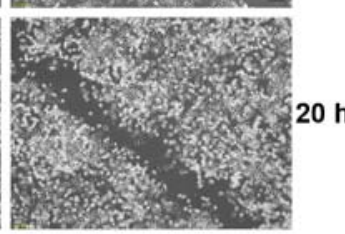

si-CXCR4+SDF-1 $\alpha$

si-CXCR4+SDF-1a+

NT21MP
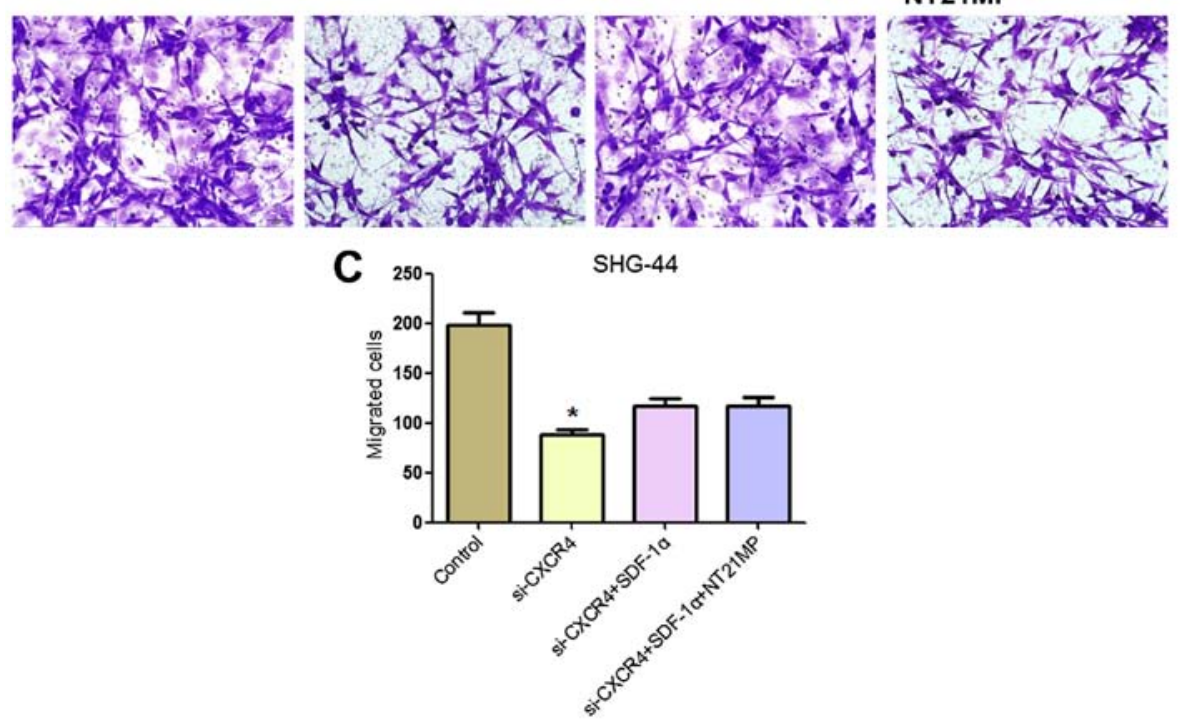

Figure 8. The migration and invasion ability of SHG-44 cells transfected with si-CXCR4 and stimulated with (+SDF-1 $\alpha$ ) or not (-SDF-1 $\alpha$ ) with $100 \mathrm{ng} / \mathrm{ml}$ of SDF-1 $\alpha$ and NT21MP $(1.0 \mu \mathrm{g} / \mathrm{ml})$. (A) Invasion ability of SHG-44 cells measured by wound healing assays. (B) Representative images and (C) the indicated invading cells analyzed by Transwell assay. Scale bar, $50 \mu \mathrm{m}$. Data are mean $\pm \mathrm{SD}$ of 5 fields. ${ }^{*} \mathrm{P}<0.05$ vs. control.

immunofluorescence analysis to investigate the expression levels of differentiation-related markers (GFAP) in glioma cells. As shown in Fig. 6, the results revealed very low expression of GFAP in the two glioma cells. Pre-treatment with NT21MP, markedly increased the expression of GFAP in U251 and SHG-44 cells. These results suggested that NT21MP increased the expression of differentiation-related markers in glioblastoma cells in vitro.

Assessment of the effect of CXCR4 siRNA in SHG-44 cells. We evaluated the mRNA expression level of SDF-1 $\alpha$ and CXCR4 in U251 and SHG-44 cells by RT-qPCR. SDF-1 $\alpha$ and CXCR4 mRNA expression in SHG-44 was significantly higher than U251 cells $(\mathrm{P}<0.05)$ (Fig. 7A). To detect the effect of siRNA targeting CXCR4 expression in SHG-44 cells, western blot analysis was performed to evaluate the expression of CXCR4 protein. As shown in Fig. 7B, transient transfection of CXCR4specific siRNA resulted in the suppression of CXCR4 protein expression, thus, siRNA3 was more effective and selected for the subsequent experiments.

Effects of NT21MP on SHG-44 cell migration and invasion after CXCR4 depletion. In order to detect the effects of
NT21MP on glioma cell, we measured the effect of CXCR4 silencing on the migration and invasion ability of cells in vitro by wound healing and Transwell assay. As shown in Fig. 8, a slower migration was observed and the number of migrated cells was significantly reduced in SHG-44 cells treated with si-CXCR4 group compared with the control group. These results indicated that the invasion and migration ability were affected by the depletion of CXCR4 in SHG-44 cells.

Cells treated with si-CXCR4-SDF-1 $\alpha$ group exhibited an increase in the number of migrated cells compared with the si-CXCR4 group. Notably, in comparison with si-CXCR4SDF-1 $\alpha$ group, the ability of migration and invasion ability of SHG-44 cells with NT21MP-si-CXCR4-SDF-1 $\alpha$ treatment was significantly decreased. These results indicated that NT21MP inhibited SHG-44 cell migration and invasion by blocking the SDF-1 $\alpha /$ CXCR4 biological axis.

Effects of NT21MP on cell cycle and apoptosis in SHG-44 cells after $C X C R 4$ silencing. In order to further define the role of NT21MP in SHG-44 cells, we next analyzed cell cycle following siRNA depletion of CXCR4 by flow cytometry. As shown in Fig. 9A and B, SHG-44 cells treated with si-CXCR4 

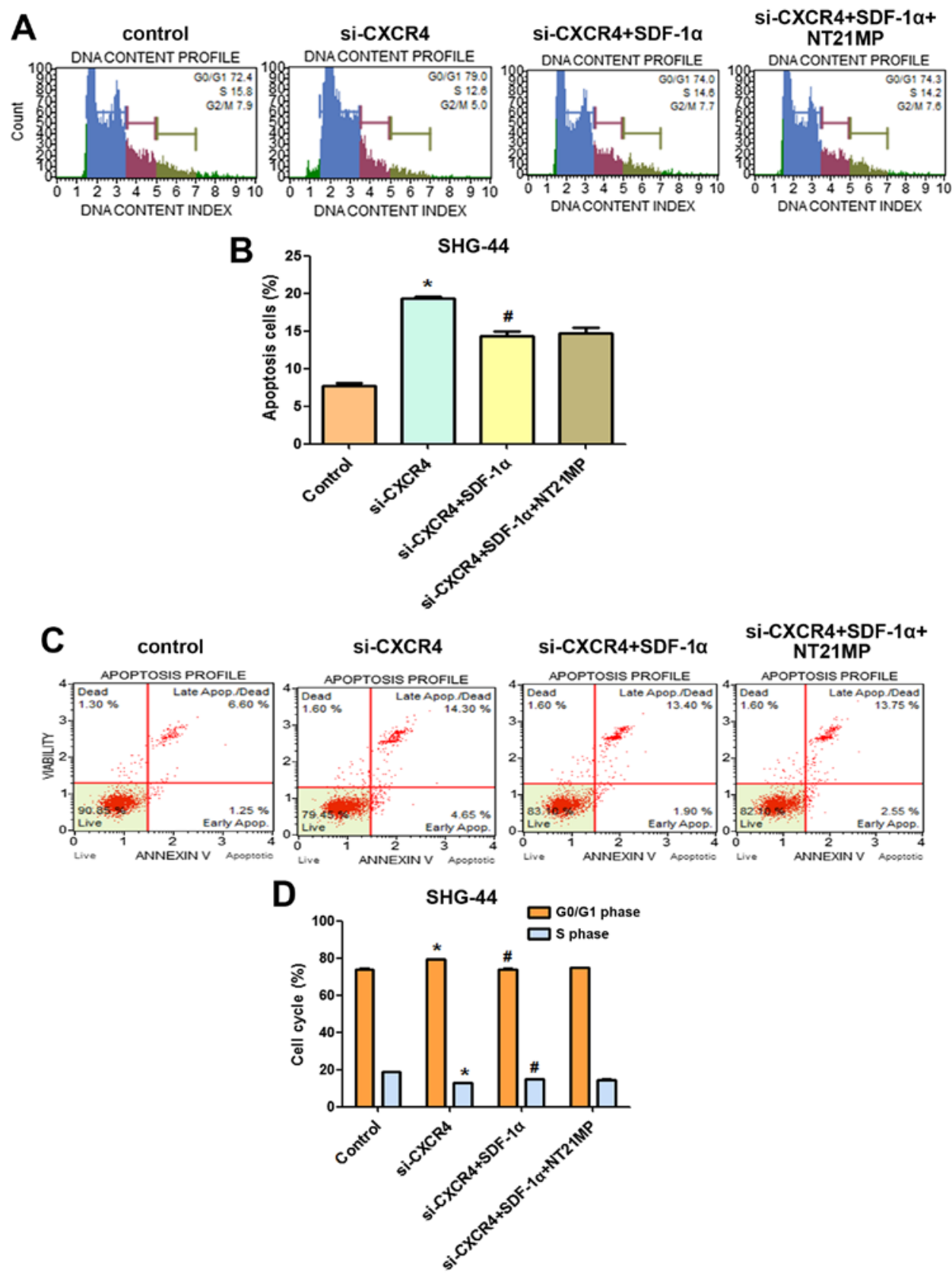

Figure 9. The cell cycle and apoptosis of SHG-44 cells transfected with si-CXCR4 and stimulated with (+SDF-1 $\alpha$ ) or not (-SDF-1 $\alpha)$ with $100 \mathrm{ng} / \mathrm{ml}$ of SDF-1 $\alpha$ and NT21MP $(1.0 \mu \mathrm{g} / \mathrm{ml})$. (A) The cell cycle of SHG-44 cells were analysized by propidium iodide staining and flow cytometry. (B) Bar plots illustrating the percentage of G0/G1 and S phase in SHG-44 cells. (C) Apoptosis of SHG-44 cells was evaluated by Annexin V/PI staining and flow cytometry. (D) Bar plots illustrating the percentage of apoptosis cells in SHG- 44 cells. Data are presented for one of triplicate experiments. ${ }^{*} \mathrm{P}<0.05$ vs. control. ${ }^{*} \mathrm{P}<0.05$ vs. transfected with si-CXCR4 group.

for the same period of time showed a significant increase in the proportion of cells in G0/G1 phase and a significant decrease in the proportion of cells in $\mathrm{S}$ phase compared with that of the control group. Treatment with si-CXCR4-SDF-1 $\alpha$ resulted in a significant decrease in the proportion of cells in G0/G1 phase and a significant increase in the proportion of cells in $\mathrm{S}$ phase. We also investigated the impact of CXCR4 siRNA and NT21MP combination therapy on SDF-1 $\alpha$-induced SHG-44 cells. In comparison with si-CXCR4-SDF-1 $\alpha$ treatment, NT21MP-si-CXCR4-SDF-1 $\alpha$ decreased the percentage of $\mathrm{S}$ phase in SHG-44 cells.

Furthermore, we analyzed cell apoptosis in different treatment groups. Compared with the control group, cell apoptosis increased after CXCR4 depletion (Fig. 9C and D), demonstrating that high expression of CXCR4 was responsible for the anti-apoptotic effect. However, the percentage of apoptotic cells in si-CXCR4-SDF-1 $\alpha$ group was lower than that of si-CXCR4 group, but NT21MP-si-CXCR4-SDF-1 $\alpha$ increased the percentage of apoptotic cells compared with the si-CXCR4-SDF-1 $\alpha$ group.

Effects of NT21MP on the expression of cell cycle and apoptosis-related genes in SHG-44 cells after CXCR4 silencing. To further explore the molecular mechanism by which NT21MP causes glioma cell arrest in G0/G1 phase and promotes apoptosis, RT-qPCR and western blotting were applied to assess 

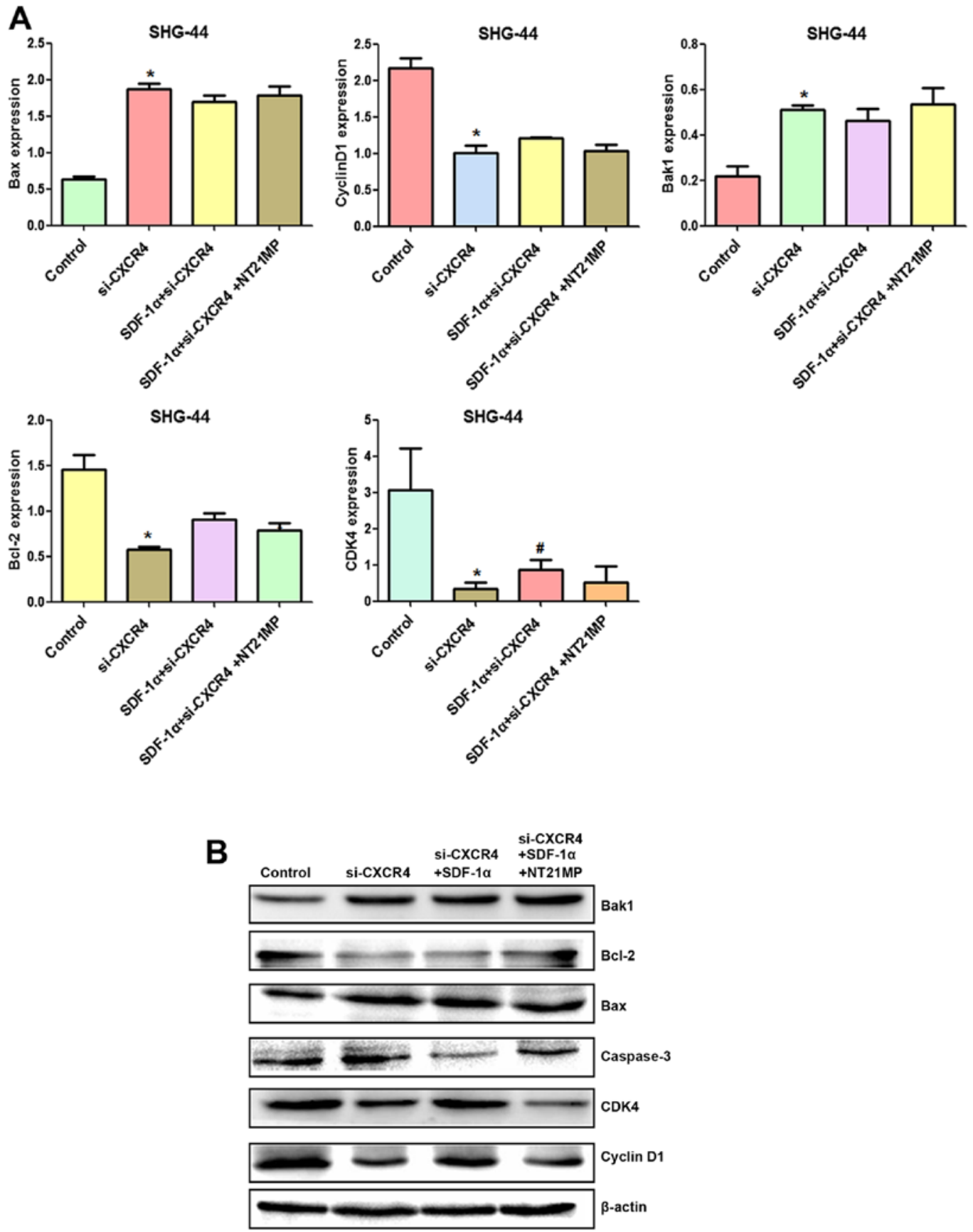

Figure 10. The expression of cell cycle and apoptosis related factors in SHG-44 cells transfected with si-CXCR4 and stimulated with (+SDF-1 $\alpha)$ or not (-SDF-1 $\alpha$ ) with $100 \mathrm{ng} / \mathrm{ml}$ of SDF-1 $\alpha$ and NT21MP $(1.0 \mu \mathrm{g} / \mathrm{ml}$ ). (A and B) Quantitative RT-PCR and western blot analyses of the mRNA and protein level of Bak1, Bcl-2, Bax, caspase-3, CDK4 and cyclin D1 in the SHG-44 cells. The data are the results of three independent experiments and are presented as mean $\pm \mathrm{SD},{ }^{*} \mathrm{P}<0.05$ vs. control. ${ }^{\#} \mathrm{P}<0.05$ vs. transfected with si-CXCR4 group. $\mathrm{P}<0.05$ vs. transfected with si-CXCR4 and $(+\mathrm{SDF}-1 \alpha)$ group.

the changes of mRNA and protein levels of cell cycle and apoptosis-related factors after CXCR4 silencing.

Compared with the control group, cyclin D1, CDK4 and Bcl-2/Bax expression levels were decreased after CXCR4 depletion, while Bak1 and caspase-3 amounts were increased (Fig. 10A and B). Combining with the results in Fig. 5, SDF-1 $\alpha$ upregulated expression of cyclin D1, CDK4 and Bcl-2/Bax and downregulated expression of Bak1 and caspase-3 slightly after CXCR4 silencing, suggesting that weakened SDF-1 $\alpha$ induced G0/G1 to $S$ phase transition and anti-apoptosis.

After CXCR4 silencing, NT21MP slightly decreased cyclin D1, CDK4 and Bcl-2/Bax levels and increased Bak1 and caspase-3 amounts slightly, suggesting that regulation by NT21MP of the above genes was significantly decreased after CXCR4 silencing. Together, these findings indicated that NT21MP caused cell cycle arrest in G0/G1 phase and promoted apoptosis by inhibiting the SDF-1 $\alpha /$ CXCR4 biological axis (Fig. 11).

\section{Discussion}

Accumulating evidence has revealed that SDF-1 $\alpha /$ CXCR4 plays a significant role in tumor genesis (17). It is known that SDF-1 $\alpha$ binds to CXCR4 and subsequently activates 

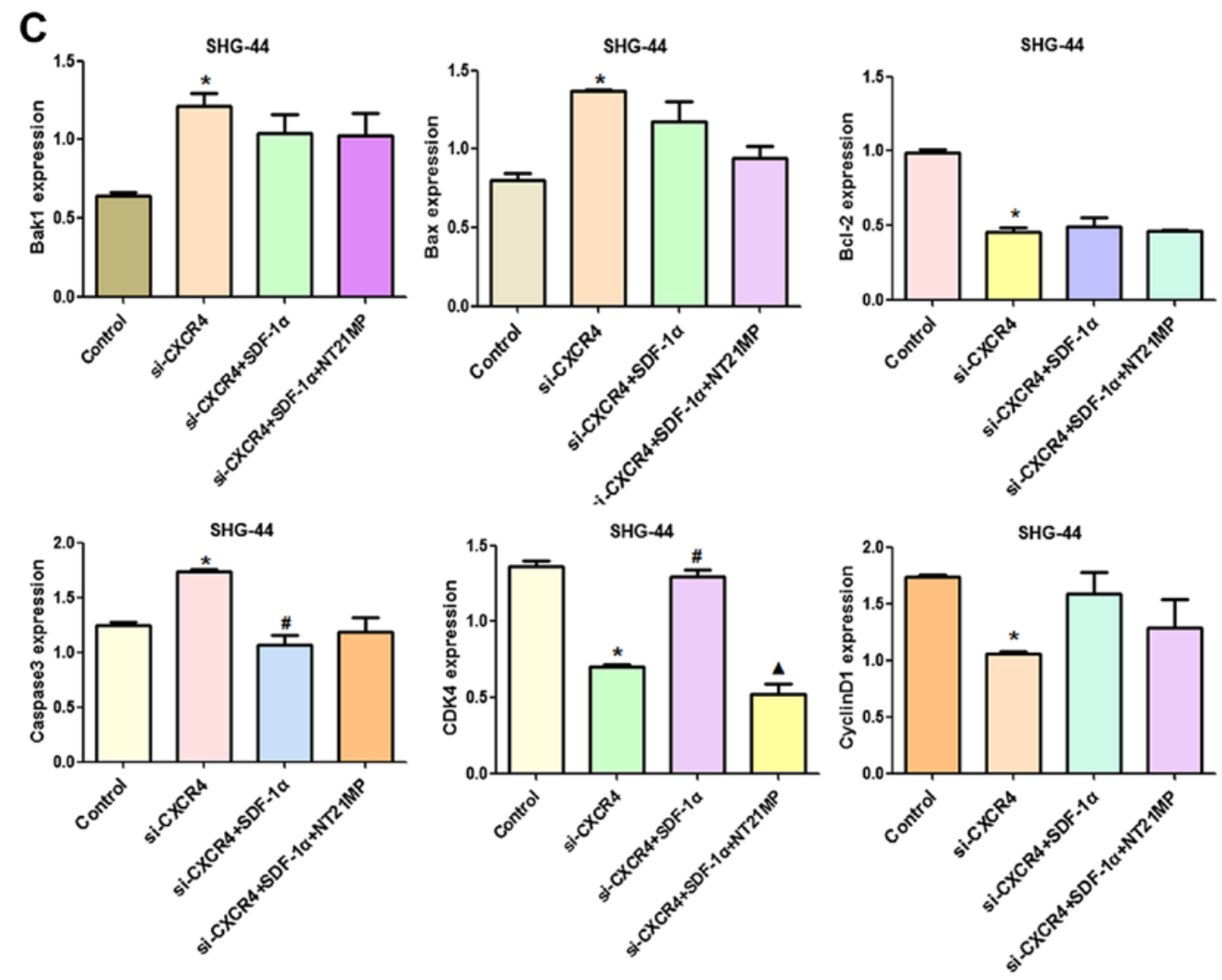

Figure 10. Continued. (C) The bar plots show the quantitative results for cell cycle and apoptosis-related proteins.

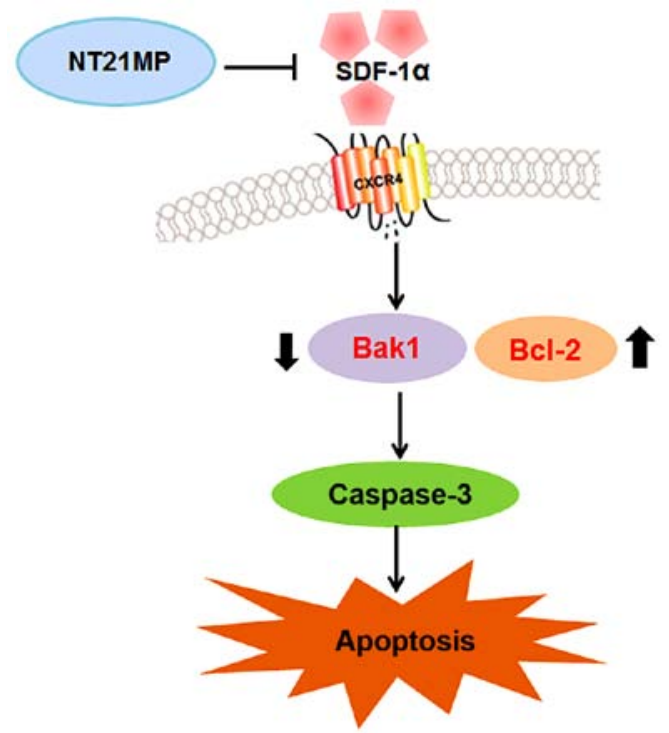

Figure 11. The signaling pathway of the molecular mechanism of NT21MP in glioma.

their multiple target genes including extracellular regulated kinase 2 (ERK2), protein kinase B (PKB), phosphatidylinositol 3-kinase (PI3K), steroid receptor coactivator (SRC) and mitogen activated protein kinase (MAPK), through these pathways CXCR4 regulates many different cellular functions including survival, growth and chemotaxis as well as having diverse effects on gene expression $(18,19)$.
The activation of CXCR4 has been reported to promote tumor growth, motility, invasion and metastasis in a variety of human cancers including glioma (20). AMD3100 is also employed in the treatment of glioma through multiple mechanisms. However, AMD3100 lacks CXCR4 specificity because it also binds the other high-affinity receptors for CXCL12, CXCR7 (10). Therefore, development of an antagonists targeting CXCR4 could provide more effective strategy for human cancers (21). To achieve better treatment of glioma, we recently developed NT21MP, which is capable of antagonising the function of CXCR4 pathway. In the present study, we found that NT21MP caused cell proliferation inhibition, cell cycle arrest and induced apoptosis in U251 and SHG-44 cells. The expression of GFAP was also markedly increased. To gain more insight into the effect of NT21MP on glioma cells, we selectively knocked down CXCR4 using siRNA and observed the subsequent effects on SHG-44 cells. Silencing of CXCR4 could inhibit cell proliferation. Moreover, in comparison with si-CXCR4-SDF-1 $\alpha$ treatment, NT21MP-si-CXCR4-SDF-1 $\alpha$ treatment decreased the ability of migration and invasion and the percentage of S phase; however, the percentage of apoptotic cells was increased. These results identified that NT21MP could be a promising agent by targeting CXCR4 for treatment of glioma.

It has been reported that SDF-1 $\alpha /$ CXCR4 could enhance cell proliferation in various human cancers $(22,23)$. For example, Barbero et al (24) reported that exogenous SDF-1 $\alpha$ promotes proliferation of glioma cells in a dose-dependent manner. In this study, we found that SDF-1 $\alpha$ promoted glioma 
cell growth, whereas NT21MP was capable of inducing growth inhibition in U251 and SHG-44 cells.

High ability of migration is a hallmark of malignant gliomas and is the main reason for therapeutic failure and recurrence of tumors (25). It is known that SDF-1 $\alpha /$ CXCR4 plays a pivotal role in cell migration and invasion in glioma (26). Thus, to further explore the anti-metastasis activity of NT21MP, we detected cell invasion in glioma cells after NT21MP treatment. We observed a marked decrease in cell invasion ability in NT21MP treated group.

Cyclin D1 is a positive cell cycle regulator during the G1/S transition (27). In addition, CDK4 is also recommended as a master regulatory protein in the cell cycle (28). We showed that SDF-1 $\alpha$ increased the active level of cyclin D1 and CDK4. Conversely, this level was decreased by NT21MP. Moreover, the combination of SDF- $1 \alpha$ and CXCR4 activates Akt to promote changes of $\mathrm{Bcl}-2$ expression. The activity and ratio of Bcl-2, Bak1 and Bax can regulate mitochondrial function and cytochrome $c$ release, playing a role in the mitochondrial pathway of apoptosis. Chen et al (29) found that Bcl-2 downregulation and Bax upregulation could change the permeability of the mitochondrial membrane, activate caspase- 9 and caspase-3, and induce apoptosis in glioma cells. Our results showed that NT21MP upregulated Bak1 and downregulated Bcl-2/Bax, further promoting caspase-3 expression and apoptosis in glioma cells.

GFAP is an intermediate filament protein, and a specific marker for astrocytes and related tumors, oligodendroglia cells and ependymocytes (30). It is expressed in normal brain tissue and glioma cells, and with the increasing glioma tumor grade the expression of GFAP was decreased (31), making GFAP a good indicator for differentiation degree and prognosis of glioma. NT21MP induced GFAP expression, suggesting a possible glioma cell transformation into normal cells.

The importance of CXCR4 in glioma biology has been inferred by others. Sehgal et al (32) found that overexpression of CXCR4 in glioma lines enhanced their soft agar colonyforming capability, whereas the treatment with antibodies to CXCR4 and SDF-1 $\alpha$ can cause inhibition of cell proliferation. Consistently, we found that silencing of CXCR4 suppressed cell migration and invasion but induced cell cycle arrest and apoptosis in SHG-44 cells. Importantly, we observed a synergistic effect between si-CXCR4 and NT21MP on cell apoptosis, migration and invasion.

In summary, this study demonstrated that through the SDF-1 $\alpha /$ CXCR4 biological axis, NT21MP exerts anti-glioma effects, blocking cell cycle, inhibiting proliferation and inducing apoptosis. These findings suggest that targeting CXCR4 may represent a potential approach to enhance the efficacy of NT21MP to treat glioma.

\section{Acknowledgements}

The present study was supported by the Major Program of Anhui Educational Committee (nos. KJ2015ZD29 and KJ2016SD37), the Natural Science Foundation of Anhui (no. 1508085MH159), the Key Program of college discipline (major) top-notch talent academic subsidize of Anhui (no. gxbjZD2016069), the Program for science research of Bengbu Medical College (nos. BYKY1419ZD and BYKY1420ZD) and the Program for graduates research of Bengbu Medical College (no. Byycx1524).

\section{References}

1. Omuro A and DeAngelis LM: Glioblastoma and other malignant gliomas: A clinical review. JAMA 310: 1842-1850, 2013.

2. Fishman $M$ and Seigne J: Immunotherapy of metastatic renal cell cancer. Cancer Control 9: 293-304, 2002.

3. Vicari AP and Caux C: Chemokines in cancer. Cytokine Growth Factor Rev 13: 143-154, 2002.

4. Li W and Graeber MB: The molecular profile of microglia under the influence of glioma. Neuro Oncol 14: 958-978, 2012

5. Flüh C, Hattermann K, Mehdorn HM, Synowitz M and HeldFeindt J: Differential expression of CXCR4 and CXCR7 with various stem cell markers in paired human primary and recurrent glioblastomas. Int J Oncol 48: 1408-1416, 2016.

6. Cho KS, Yoon SJ, Lee JY, Cho NH, Choi YD, Song YS and Hong SJ: Inhibition of tumor growth and histopathological changes following treatment with a chemokine receptor CXCR4 antagonist in a prostate cancer xenograft model. Oncol Lett 6: 933-938, 2013.

7. Maddirela DR, Kesanakurti D, Gujrati M and Rao JS: MMP-2 suppression abrogates irradiation-induced microtubule formation in endothelial cells by inhibiting $\alpha \mathrm{v} \beta 3$-mediated SDF-1/CXCR4 signaling. Int J Oncol 42: 1279-1288, 2013.

8. Sekuła M, Miekus K and Majka M: Downregulation of the CXCR4 receptor inhibits cervical carcinoma metastatic behavior in vitro and in vivo. Int J Oncol 44: 1853-1860, 2014.

9. Broxmeyer HE, Orschell CM, Clapp DW, Hangoc G, Cooper S, Plett PA, Liles WC, Li X, Graham-Evans B, Campbell TB, et al: Rapid mobilization of murine and human hematopoietic stem and progenitor cells with AMD3100, a CXCR4 antagonist. J Exp Med 201: 1307-1318, 2005.

10. Labrosse B, Brelot A, Heveker N, Sol N, Schols D, De Clercq E and Alizon M: Determinants for sensitivity of human immunodeficiency virus coreceptor CXCR4 to the bicyclam AMD3100. J Virol 72: 6381-6388, 1998.

11. Kalatskaya I, Berchiche YA, Gravel S,Limberg BJ, Rosenbaum JS and Heveker N: AMD3100 is a CXCR7 ligand with allosteric agonist properties. Mol Pharmacol 75: 1240-1247, 2009.

12. Khan A, Greenman J and Archibald SJ: Small molecule CXCR4 chemokine receptor antagonists: Developing drug candidates. Curr Med Chem 14: 2257-2277, 2007.

13. Kledal TN, Rosenkilde MM, Coulin F, Simmons G, Johnsen AH, Alouani S, Power CA, Lüttichau HR, Gerstoft J, Clapham PR, et al: A broad-spectrum chemokine antagonist encoded by Kaposi's sarcoma-associated herpesvirus. Science 277: 1656-1659, 1997.

14. Yang QL, Ding YQ, Chen CJ, Tang J, Zhang J and Yang ZF: Suppression of murine breast cancer metastasis by selective inhibition of CXCR4 by synthetic polypeptide derived from viral macrophage inflammatory protein II. Chin Sci Bull 55: 2152-2159, 2010.

15. Yang Q, Chen C, Yang Z, Gao Y and Tang J: Suppression of breast cancer proliferation and induction of apoptosis via AKT and ERK1/2 signal transduction pathways by synthetic polypeptide derived from viral macrophage inflammatory protein II. J Huazhong Univ Sci Technolog Med Sci 31: 497-503, 2011.

16. Yang QL, Ding YX, Chen CJ, Yang ZF and Gao YJ: The mechanism of polypeptide derived from viral macrophage inflammatory protein II modulates SDF-1 $\alpha /$ CXCR4-induced migration. Xi Bao Yu Fen Zi Mian Yi Xue Za Zhi 28: 137-140, 2012 (In Chinese).

17. Domanska UM, Kruizinga RC, Nagengast WB, TimmerBosscha H, Huls G, de Vries EG and Walenkamp AM: A review on CXCR4/CXCL12 axis in oncology: No place to hide. Eur $\mathrm{J}$ Cancer 49: 219-230, 2013.

18. Epstein RJ: The CXCL12-CXCR4 chemotactic pathway as a target of adjuvant breast cancer therapies. Nat Rev Cancer 4: 901-909, 2004

19. Portella L, Vitale R, De Luca S, D'Alterio C, Ieranò C, Napolitano M, Riccio A, Polimeno MN, Monfregola L, Barbieri A, et al: Preclinical development of a novel class of CXCR4 antagonist impairing solid tumors growth and metastases. PLoS One 8: e74548, 2013. 
20. Berghuis D, Schilham MW, Santos SJ, Savola S, Knowles HJ Dirksen U, Schaefer KL, Vakkila J, Hogendoorn PC and Lankester AC: The CXCR4-CXCL12 axis in Ewing sarcoma: Promotion of tumor growth rather than metastatic disease. Clin Sarcoma Res 2: 24-32, 2012.

21. Peled A, Wald O and Burger J: Development of novel CXCR4based therapeutics. Expert Opin Investig Drugs 21: 341-353, 2012.

22. Skommer J, Wlodkowic D and Pelkonen J: CXCR4 expression during tumour cell death. Leuk Res 31: 1155-1156, 2007.

23. Teicher BA and Fricker SP: CXCL12 (SDF-1)/CXCR4 pathway in cancer. Clin Cancer Res 16: 2927-2931, 2010.

24. Barbero S, Bonavia R, Bajetto A, Porcile C, Pirani P, Ravetti JL, Zona GL, Spaziante R, Florio T and Schettini G: Stromal cellderived factor lalpha stimulates human glioblastoma cell growth through the activation of both extracellular signal-regulated kinases 1/2 and Akt. Cancer Res 63: 1969-1974, 2003.

25. Tu H, Zhou Z, Liang Q, Li Z, Li D, Qing J, Wang H and Zhang L: CXCR4 and SDF-1 production are stimulated by hepatocyte growth factor and promote glioma cell invasion. Onkologie 32: 331-336, 2009.

26. Ehtesham M, Winston JA, Kabos P and Thompson RC: CXCR4 expression mediates glioma cell invasiveness. Oncogene 25 : 2801-2806, 2006.
27. Koepp DM, Schaefer LK, Ye X, Keyomarsi K, Chu C, Harper JW and Elledge SJ: Phosphorylation-dependent ubiquitination of cyclin E by the SCFFbw7 ubiquitin ligase. Science 294: 173-177, 2001.

28. Tamamori-Adachi M, Ito H, Sumrejkanchanakij P, Adachi S, Hiroe M, Shimizu M, Kawauchi J, Sunamori M, Marumo F, Kitajima S, et al: Critical role of cyclin D1 nuclear import in cardiomyocyte proliferation. Circ Res 92: 9-12, 2003.

29. Chen S, Zhu L, Huang J, Cai Y, Lu X, Yang Q, Wu Q, Chen C and Wang Z: Arsenic trioxide targets miR-125b in glioma cells. Curr Pharm Des 20: 5354-5361, 2014.

30. Middeldorp J and Hol EM: GFAP in health and disease. Prog Neurobiol 93: 421-443, 2011.

31. Zhou J, Liu Q, Wang J, Guo X and Song L: Expressions of peroxiredoxin 1, peroxiredoxin 6 and GFAP in human brain astrocytoma and their clinical significance. Nan Fang Yi Ke Da Xue Xue Bao 32: 1255-1259, 2012 (In Chinese).

32. Sehgal A, Keener C, Boynton AL, Warrick J and Murphy GP: CXCR-4, a chemokine receptor, is overexpressed in and required for proliferation of glioblastoma tumor cells. J Surg Oncol 69: 99-104, 1998. 